\title{
Results of plasma-impulse technology application at uranium Inkay deposit, Kazakhstan
}

\author{
A.V. Chekulaev \\ Geophysic Engineer of Scientific-production center «GeoMIR», Saint-Petersburg, Russia
}

\begin{abstract}
A.S. Egorov
Doctor of Geological and Mineralogical Scienses, Head of the Department of Geophysical and Geochemical Methods of Prospecting and Exploration of Mineral Deposits, Saint-Petersburg Mining University, SaintPetersburg, Russia
\end{abstract}

\begin{abstract}
A.A. Molchanov
Doctor of Engineering Sciences, Proffessor at the Department of Geophysical and Geochemical Methods of Prospecting and Exploration of Mineral Deposits, Saint-Petersburg Mining University, Saint-Petersburg, Russia
\end{abstract}

\begin{abstract}
This article discusses the methodology for increasing the uranium extraction, in the process of development of hydrogen type uranium deposits of the Republic of Kazakhstan. The analysis of the effectiveness of the standard repair work and methods was applied. The plasma-impulse technology (PIT) using is proposed to increase the permeability of the ore-layer decolmatate the well filters and as a result, intensify the leaching process. The article reviews the physical impact of PIT on the reservoir. Due to the resonant effects in the reservoir as a result of the elastic impact, the process of uranium transition to the mobile form is intensified. A schematic model of the elastic resonance action on a uranium-containing ore-layer using PIT is presented. Positive results were obtained on the application of the proposed technology on some uranium ore deposits of the Republic of Kazakhstan at all stages of their development while the opening of a deposit, blocks acidification and leaching. Based on the results of testing the technology, a combination of PIT with standard methods of repair and restoration work was developed. The application of the author's methodology intensifies the process of uranium transition to the mobile form due to resonance at dominant frequencies and stabilizes the metal yield. High flow rates of pumping wells with an increased or stable metal yield will increase uranium production, its extraction rate and, accordingly, shorten the life of the deposit.
\end{abstract}

\section{INTRODUCTION}

The method of the drillhole in situ leaching (ISL) in uranium deposits was developed and widely used in the Republic of Kazakhstan. It is characterized by high environmental safety, low costs and simplification of technological operations (Turaev. N. \& Zherin. I. 2005). ISL development system is considered to be the specified mode of technological wells. The principal operations of the ISL technological system are the well injecting, pumping and monitoring (Figure 1).

Sulfuric acid solution with a concentration of 5-30 grams per liter, less often up to 50 grams per liter, is used as a leaching reagent (acid solution). The acid solution is supplied through injection wells and penetrated into ore horizons, where selective transfer of natural uranium ions to a productive solution takes place. The productive solution with dissolved uranium rises to the surface through pumping wells. Monitoring wells are used for observation and process control. 


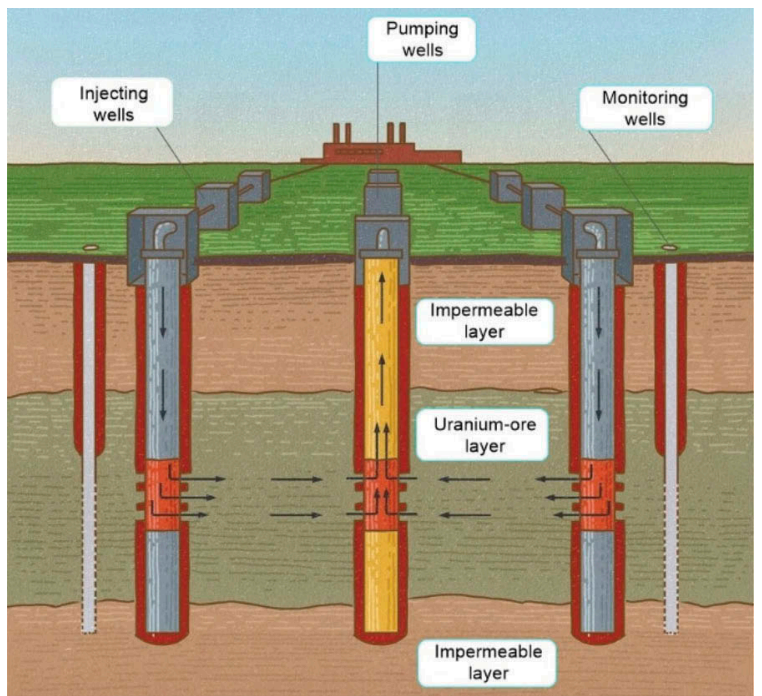

Figure 1. Technological scheme of drillhole in situ leaching of hydratogenous uranium deposits.

\section{PROBLEM DEFINITION}

It should be noted that the leaching rate in beds depends on many geological and technological parameters. There are two principal parameters - the coefficient of permeability of ore horizons and the uranium concentrations. Due to high permeability of the sedimentary reservoirs at a low metal values of hydratogenous uranium deposits, the drillhole in situ leaching method is the only possible method for their efficient and profitable development.

The decreasing of productive intervals permeability is one of the principal problems of ISL method application to the due to the clogging (colmatation) of well-filters (Evteeva L., 2002) and near-well zones of technological wells (Gorbatenko O. et al, 2018). A similar problem is observed in the process of development of uranium deposits in Kazakhstan in depths more than 500 meters. It is necessary to achieve high production rates of pumping wells, to ensure a stable metal yield, to increase the interrepair cycles (IRC) in technological wells, and to reduce the number and time of repair and restoration works (RRW). Therefore, the solution of this problem is of significant technological and economic interest.

Currently, there are standart technologies increasing well productivity. There are three principial types of RRW applied to recover the permeability:

- physical methods of RRW - flushing, pumping by airlift, hydrodynamic and pneumatic treatments;

- chemical methods of RRW based on the using of highly concentrated sulfuric acid or ammonium fluoride;

- physicochemical (complex) methods of RRW.

Each of the RRW methods has its advantages and disadvantages, however, the average interrepair cycle of wells achieves 20 - 25 days, sometimes achieves $1.5-2.0$ months. Besides, application of standart RRW methods requires the shutdown of wells and the additional expenses.

Our investigations have shown that the main well colmatant is drilling clay. The clay content in the solid phase varies from 42 to $98.2 \%$ and on average is of $76 \%$. The rest part of the colmatant is represented by the sand of various fractions, mainly from 0.1 to $0.5 \mathrm{~mm}$, destroyed in the process of ion exchange in the injecting wells and insignificant amounts of gypsum. 


\section{METHODOLOGY}

To increase the uranium extraction, the authors developed and patented plasma-impulse technology (PIT) for creating a series of high - power electrohydraulic impulses in the hydrosphere of the well (Molchanov A. et al, 2014). The manufactured equipment "Pritok-1M" (Figure 2) can be used for decalmation of the well-filter, wellbore zone, and interwell space to restore the permeability of the reservoir and increase the mobility of the acid solution (RU Pat. No. 2685381 to LLC SPC «GeoMIR»). This technology has been successfully tested in the Inkai uranium field.

This process of plasma - impulse action occurs due to the expansion of the plasma channel and its subsequent "collapse", which has alternating stresses on the filter, near the wellbore zone and on the reservoir as a whole (Molchanov A. \& Chekulaev A., 2019). As a result of repeating repression-depression cycles, elastic hydraulic waves propagate along with the bedlayer skeleton and in its porous medium, improve the capacitive and filtration properties of this bed-layer. At the same time, the filter intervals and the near-well zone are cleared from the clay and mud slush colmatant particles, as well as the precipitation of salts.

Pressure impulses open the natural channels in the reservoir and contribute to the formation of new ones that have increased hydraulic conductivity (Figure 3). Due to the resonant effects in the reservoir as a result of the elastic impact, the process of transition of uranium to the mobile form is intensified (Molchanov A. \& Chekulaev A.,, 2019). The penetration depth of
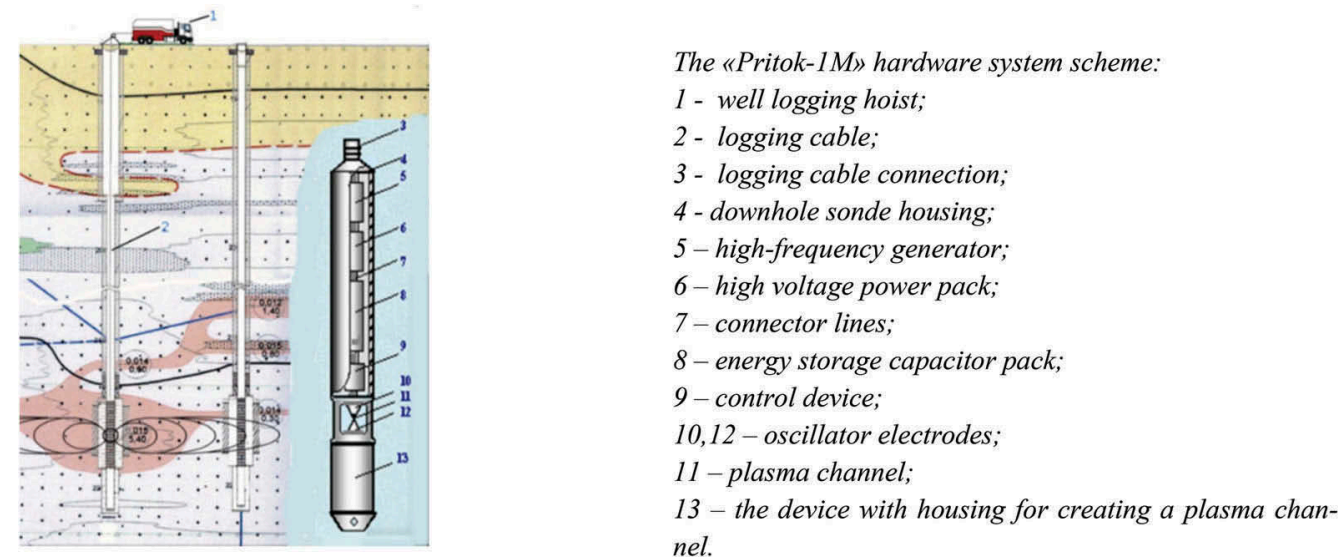

Figure 2. Construction of the «Pritok-1M» hardware system.

$A$
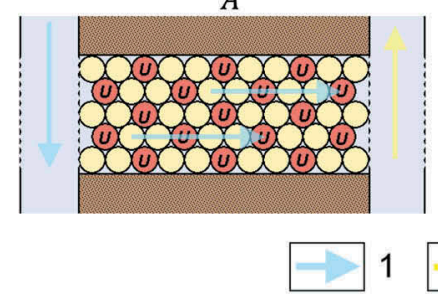
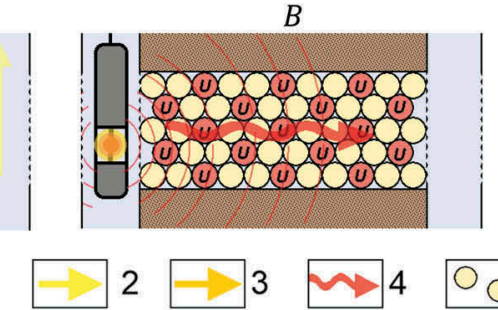
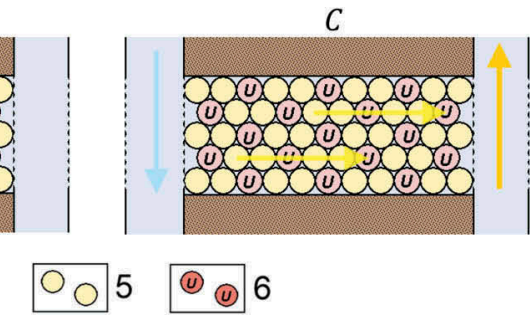

Figure 3. Schematic model of the plasma-impulse impact on the ore-layer. A- the usual model of uranium leaching. B- the ore-layer treatment by PIT. C - intensified leaching process. 1 - direction of injected acid solution; 2- direction of acid solution with a low concentration of uranium; 3- direction of acid solution with a high concentration of uranium; 4- elastic wave exposure of PIT; 5- rock grains; 6-uraniumcontaining rock grains. 
elastic energy due to directional radiation achieves 50-75 meters or more, which significantly exceeds the exposure range of the traditionaly applied RRW methods and, in combination with acid treatment, contributes to deeper leaching of metal from wells of long-operating cells with low uranium extraction (Molchanov A. \& Demekhov., 2014).

\section{RESULTS}

Application of PIT in the period of the blocks acidification provides reducing the time of uranium transition to the mobile form and to intensify the leaching process due to the deep penetration of the acid solution into the interwell space. It also provides the uranium extraction and high production rates of pumping wells for a long time with an IRC of 80 - 120 days. (Table 1).

Table 1. Operating mode of wells after the PIT application (LLP "JV"Inkai" 2016-2017 y.).

\begin{tabular}{|c|c|c|c|c|c|c|c|}
\hline № & $\begin{array}{l}\text { Number } \\
\text { of well }\end{array}$ & Date of RRW & $\begin{array}{l}\text { production rate after } \\
\text { PIT, } \mathrm{m}^{3} / \text { hour }\end{array}$ & $\begin{array}{l}0.7 \text { production rate } \\
\text { after } \mathrm{PIT}, \mathrm{m}^{3} / \text { hour }\end{array}$ & $\begin{array}{l}\text { IRC, } \\
\text { days }\end{array}$ & $\begin{array}{l}\mathrm{Q} / \mathrm{Q}_{\max } \\
\%\end{array}$ & $\mathrm{U}, \mathrm{mg} /$ \\
\hline 1. & $30-6-3$ & 10.05 .16 & $8.30-1.84$ & 5,81 & 50 & 22 & 15 \\
\hline 2. & $30-6-4$ & 11.05 .16 & 8,89 & 6,22 & 65 & 63 & 17,4 \\
\hline 3. & $32-0 \mathrm{~d}-1$ & 26.11 .16 & 8,01 & 5,60 & 45 & 48 & 34,3 \\
\hline 4. & $32-2-2$ & 24.11 .16 & 11,04 & 7,728 & 120 & 55 & $31-23$ \\
\hline 5. & $32-4-4$ & 14.12 .16 & 7,88 & 5,51 & 120 & 42 & $44,4-31$ \\
\hline 6. & $32-6-3$ & 22.11 .16 & 9,53 & 6,671 & 50 & 57 & 42,6 \\
\hline 7. & $80-6-1$ & 08.08 .16 & 9,23 & 6,46 & 30 & 62 & 84,3 \\
\hline 8. & $80-6-4$ & 05.05 .16 & 9,82 & 6,87 & 75 & 78 & 47,4 \\
\hline 9. & $80-8-3$ & 26.11 .16 & 7,35 & 5,14 & 180 & 77 & 55 \\
\hline 10. & $16-18 d-3$ & 06.12 .16 & \multicolumn{5}{|c|}{ The bottom of the well filter after the PIT was filled with sand } \\
\hline 11. & $16-20 d-5$ & 11.12 .16 & 11,33 & 7,93 & 240 & 71 & 45,6 \\
\hline 12. & $16-26 \mathrm{~d}-2$ & 16.12 .16 & 5,01 & 3,50 & 120 & 23 & $90-64$ \\
\hline 13. & $81-6-3$ & 19.12 .16 & 12,63 & 8,84 & 240 & 80 & 274 \\
\hline 14. & $81-4-1$ & $\begin{array}{l}\text { Without PIT } \\
\text { treatment } \\
\text { (control) }\end{array}$ & 10.25 & 7,17 & 230 & 96 & 162 \\
\hline
\end{tabular}

To study the effectiveness of the PIT treatment in wells in the period of their acidification, the commissioned well No.81-6-3 was treated with a complex of PIT and pneumatic pumping. The control well No.81-4-1 (without any treatment) was located in the same cell. The increase in metal extraction in No.81-6-3 well occurred in 12 days earlier than in the control well No.81-4-1. The metal extraction in the samples stabilized at the value of $264 \mathrm{mg}$ per liter and lasted more than 150 days. In the control well: output - $174 \mathrm{mg}$ per liter. Over the period from January 20 to June 9 in the No.81-6-3 well treated by PIT, the metal extraction was $43.2 \%$ higher than in the untreated control well 81-4-1 (Figure 4).

Moreower, this technology has been successfully tested at the Akdala uranium field, Central and East Mynkuduk uranium fields of the Republic of Kazakhstan. So, RRW applying PIT in the mynkuduk and inkuduk-horizons were carried out in 36 pumping and 54 injection wells. During development after drilling, acidification and leaching of technological blocks No. 30 , No. 32 , No. 16 , No. 80 , No. 81 , No. 83 and No. 66, the IRC increased from 15-20 days to $80-150$ days, with the flow rates of pumping wells within $10-11 \mathrm{~m}^{3} / \mathrm{h}$, an increase, and stabilization of the metal yield are observed. 


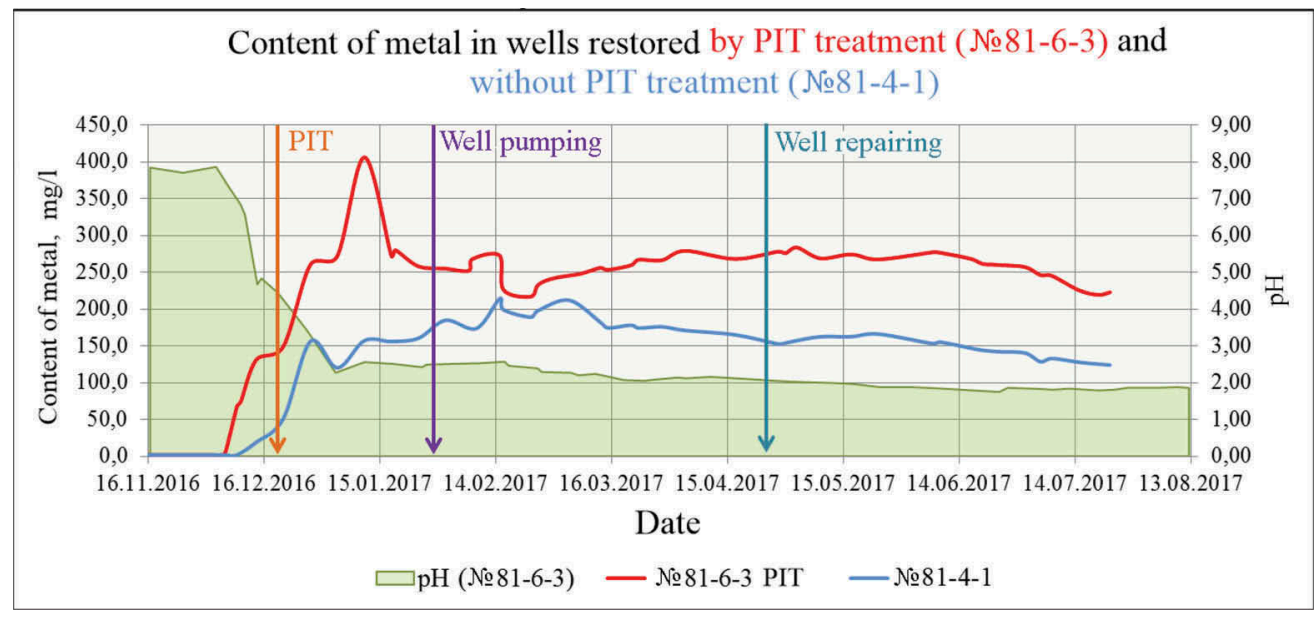

Figure 4. Comparison of metal extraction in wells No. 81-6-3 and No. 81-4-1.

\section{CONCLUSION}

1. The author's plasma-impulse technology (PIT) accelerates the transition of uranium in sedimentary layers to the mobile form due to the parametric resonance of layers at dominant frequencies.

2. Applying the PIT in combination with standard methods of repair and restoration works (RRW) provides deep cleaning of the filter and the near-wellbore zone, as well as intensify the operating modes of technological wells at all stages in the process of uranium deposits development.

3. Experience in the application of PIT at the Inkai uranium field demonstrated opportunities of the efficiency increasing of uranium development. It was justified by our investigations of 36 pumping and 54 injection wells of the inkuduk and mynkuduk horizons in the Inkai uranium field at various stages of it's development. At the same time, the interrepair cycle of pumping wells increases in several times, which allows reducing the number of RRW and, accordingly, reduce the production expenses.

\section{REFERENCES}

Gorbatenko, O. 2018. The results and prospects of applying plasma impulse technology for increasing of efficiency of technological wells operating mode of uranium from deposits which are developed by the method of drillhole in situ leaching (Inkay deposit, republic of Kazakhstan). A.Molchanov \& A.Chekulaev. 25 World Mining Congress. 2018. Kazakhsatn, Astana.

Evteeva, L. 2002. Types of well collation during underground uranium leaching and methods of struggle. II International Scientific and Practical Conference "Actual problems of uranium industry", JSC "NAC Kazatomprom", Almaty, 2002.

Molchanov, A. \& Demekhov, Y. 2014. Increasing the efficiency of uranium mining from deposits of hydrogenous type, developed by the method of underground well leaching of the Republic of Kazakhstan (on the example of the Vostochny Mynkuduk deposit). VII International Scientific and Practical Conference. "Actual problems of uranium industry", Almaty, 92-98. September 25-27, 2014.

Molchanov, A. 2018. Plasma-impulse technology applying for intensification of hydratogenous uranium deposits. Y.Demekhov \& A. Chekulaev «Ecology and social development». № 4. 34 42. 2018.

Molchanov, A. 2014. Plasma-impulse technology application for increasing the efficiency of uranium extraction from hydrogenous type deposits, developed by the drillhole in situ leaching". D.Dmitriev \& V.Sidora. Scientific and technical bulletin "Karotaznik", No. 3, 29-40. 2014. 
Molchanov. A. \& Chekulaev. A. 2019. Efficiency of parametric resonance application to the process of mining ore deposits developed by the method of underground well leaching. Scientific and technical bulletin "Karotaznik" No. 295, 3-14. 2019.

Patent of the Russian Federation, No. 2685381 "Method of uranium and related elements extraction on the technology of drillhole in situ leaching with plasma-impulse effect on the hydrosphere of the well" (priority 15.05.2018), patentee: LLC SPC “GEOMIR" (RU).

Turaev. N. \& Zherin. I. 2005. Chemistry and Technology of Uranium: A Textbook for Universities/Moscow. Federal state unitary enterprise central scientific research institute of economics of information of "ROSATOM", 2005. p. 83-89. 